Abstracta Iranica Iranica

Revue bibliographique pour le domaine irano-aryen

Volume 30 | 2010

Comptes rendus des publications de 2007

\title{
«Marlik and Toul-i Talish: A Dating Problem ». Iranica Antiqua, vol. XLII, pp. 125-138, 2 fig.
}

\section{Rémy Boucharlat}

\section{(2) OpenEdition}

1 Journals

Édition électronique

URL : http://journals.openedition.org/abstractairanica/37697

DOI : 10.4000/abstractairanica.37697

ISSN : 1961-960X

\section{Éditeur :}

CNRS (UMR 7528 Mondes iraniens et indiens), Éditions de l'IFRI

\section{Édition imprimée}

Date de publication : 8 avril 2010

ISSN : 0240-8910

\section{Référence électronique}

Rémy Boucharlat, " «Marlik and Toul-i Talish: A Dating Problem ». Iranica Antiqua, vol. XLII, pp. 125-138, 2 fig. », Abstracta Iranica [En ligne], Volume 30 | 2010, document 97, mis en ligne le 08 avril 2010, consulté le 26 septembre 2020. URL : http://journals.openedition.org/abstractairanica/ 37697 ; DOI : https://doi.org/10.4000/abstractairanica.37697

Ce document a été généré automatiquement le 26 septembre 2020.

Tous droits réservés 


\section{« Marlik and Toul-i Talish: A Dating Problem ». Iranica Antiqua, vol. XLII, pp. 125-138, 2 fig.}

Rémy Boucharlat

Parmi le matériel d'une nécropole du Talesh, celui d'une tombe collective en particulier (mais la fouille est mal publiée), un bracelet en bronze portant une courte inscription en urartéen a servi d'argument au fouilleur pour dater l'ensemble des $\mathrm{VIII}^{\mathrm{e}}$ et $\mathrm{VII}{ }^{\mathrm{e}} \mathrm{s}$. av. J.-C., ramenant à la même date la célèbre nécropole Marlik qui offre un mobilier en partie comparable. L'A. montre que cet objet, qui a pu servir longtemps, ainsi que d'autres trouvés dans cette tombe, sont à dater des $\mathrm{V}^{\mathrm{e}}$ et $\mathrm{IV}^{\mathrm{e}}$ siècles. Ils témoignent d'une réutilisation de la structure. Aucune raison donc d'abaisser la date de Marlik.

\section{INDEX}

Thèmes : 3.2.2. Pré-Achéménides et Achéménides

\section{AUTEURS}

RÉMY BOUCHARLAT

CNRS - Lyon 